\title{
One heritage corrosion product less: basic sodium copper carbonate
}

\author{
Gerhard Eggert $^{1 *}$, Andrea Fischer ${ }^{1}$ and Robert E. Dinnebier ${ }^{2}$
}

\begin{abstract}
Basic sodium copper carbonate, $\mathrm{Na}_{3}\left[\mathrm{Cu}_{2}\left(\mathrm{CO}_{3}\right)_{3}(\mathrm{OH})\right] \cdot 4 \mathrm{H}_{2} \mathrm{O}$, has been mentioned as heritage corrosion product of copper alloys in two publications. The identification relied on the comparison of the powder diffractograms with ICDD 28-1048. But this erroneous reference card clearly measured chalconatronite, $\mathrm{Na}_{2} \mathrm{Cu}\left(\mathrm{CO}_{3}\right)_{2} \cdot 3 \mathrm{H}_{2} \mathrm{O}$, instead which is indeed the product formed in the synthesis on which the card is based. Therefore, ICDD 28-1048 should be deleted.
\end{abstract}

Keywords: Basic sodium copper carbonate, Chalconatronite, Copper corrosion products,

Sodium tricarbonatohydroxodicuprate(II) tetrahydrate

\section{Background}

The aim of the Stuttgart RACoPhINO programme ('Rare Corrosion Phenomena of Inorganic Objects') is to identify hitherto unknown phenomena and compounds occurring during the deterioration of heritage objects. Even after nearly 240 years of scientific studies on heritage objects since the identification of cuprite on a Roman bronze leg in 1779 [1] it is still possible to detect new copper corrosion products. This has been demonstrated recently in our GIMME research (Glass Induced Metal-corrosion on Museum Exhibits) for dicopper formate trihydroxide, $\mathrm{Cu}_{2} \mathrm{HCOO}(\mathrm{OH})_{3}[2,3]$, and sodium copper formate hydroxide oxide hydrate, $\mathrm{Cu}_{4} \mathrm{Na}_{4} \mathrm{O}(\mathrm{HCOO})_{8}(\mathrm{OH})_{2} \cdot 4 \mathrm{H}_{2} \mathrm{O}$ [4].

But in this case, it is the other way round: we present experimental and theoretical evidence that a rare copper compound identified on metal heritage in the literature is non-existing: basic sodium copper carbonate, $\mathrm{Na}_{3}\left[\mathrm{Cu}_{2}\left(\mathrm{CO}_{3}\right)_{3}(\mathrm{OH})\right] \cdot 4 \mathrm{H}_{2} \mathrm{O}$.

\section{The evidence for basic sodium copper carbonate Reports}

Nandi and Sengupta [5, 6] reported the synthesis and characterization of the basic sodium copper carbonate

\footnotetext{
*Correspondence: gerhard.eggert@abk-stuttgart.de

1 State Academy of Art and Design, Objects' Conservation, Am

Weissenhof 1, 70191 Stuttgart, Germany

Full list of author information is available at the end of the article
}

$\mathrm{Na}_{3}\left[\mathrm{Cu}_{2}\left(\mathrm{CO}_{3}\right)_{3}(\mathrm{OH})\right] \cdot 4 \mathrm{H}_{2} \mathrm{O}$ (compound (1), sodium trica rbonatohydroxodicuprate(II) tetrahydrate) in 1972/4. The only other occurrence of (1) in the literature identifiable with a Chemical Abstract search (CAS no. 55521-72-7) is our first review of the GIMME phenomenon in 2010 [7]. In the discussion of chalconatronite $\left(\mathrm{Na}_{2} \mathrm{Cu}\left(\mathrm{CO}_{3}\right)_{2} \cdot 3 \mathrm{H}_{2} \mathrm{O}\right.$, a joint corrosion product of soda glass in contact with copper alloys in clean air free from formaldehyde) it was noted that (1) has been mentioned by Barger and White [8] to occur on a cover glass of a daguerréotype (copper plate with photo-sensitized silver layer). Identified with X-ray Powder Diffraction (XRPD), it was not included in their earlier original research paper on corrosion products [9]. Bellendorf [10] also identified (1) by XRPD together with chalconatronite in five corrosion samples from fourteen to eighteenth cent. burial plates in Franconian chapels in Bamberg and Rothenburg ob der Tauber cast from quaternary copper alloys $(\mathrm{Cu} / \mathrm{Zn} / \mathrm{Sn} / \mathrm{Pb})$. Here the sodium most likely originates from migrating salts in the wall plaster, not from soda glass.

Therefore, we tried to synthesize (1) as reference for our GIMME research (e.g., for Raman spectra).

\section{Synthesis}

(1) was prepared by Sengupta and Nandi 'by adding $50 \mathrm{ml}$ of copper(II) acetate $(3.2 \mathrm{~g})$ solution to $250 \mathrm{ml}$ $\mathrm{NaHCO}_{3}(10 \%)$. The light blue needle-shaped crystals were filtered, washed and dried' [6]. Our analyses 
by XRPD of products obtained that way surprisingly found chalconatronite as only crystalline phase. Rietveld refinement of the pattern proved the presence of amorphous material as well (estimated to 10 to $14 \%$, depending on washing).

As (1) is a basic salt (i.e., it contains a hydroxide anion) in opposite to the 'neutral' chalconatronite, one might assume that raising the $\mathrm{pH}$ might help to precipitate the basic compound. But by using a sodium hydrogencarbonate/carbonate buffer chalconatronite is definitely synthesized as Sengupta and Nandi report themselves [6] (see also [11: 353] for a similar synthesis). At even higher $\mathrm{pH}$, by using sodium carbonate (soda) alone, we yielded a totally amorphous product. Gettens and Frondel [12], the discoverer of the mineral chalconatronite, obtained 'a pale blue-green precipitate closely similar to chalconatronite in chemical composition... and other properties...simply by grinding in a mortar copper acetate in a saturated solution of sodium carbonate, allowing to stand overnight, filtering, washing and drying.' Erdös [13] grew chalconatronite on copper wetted with $10 \%$ soda solution.

By no way, (1) could be synthesized. Therefore, the physico-chemical data reported for (1) were compared to those for chalconatronite.

\section{X-ray powder diffraction}

Sengupta and Nandi used $\mathrm{Cu}-\mathrm{K} \alpha$ radiation, no further instrumental details given [6]. As they started their measurement from $2 \Theta=20^{\circ}$ (common experimental value: $5^{\circ}$ ) on, reflections for lower angles (i.e., $\mathrm{d}>4.5 \AA$ ) are simply missed. Their data have been entered as ICDD 28-1048 in the reference database with the comment ' $\mathrm{o}=$ doubtful'. If compared with our own measurement of a synthetic chalconatronite sample or with diffraction values derived from the crystal structure ([14], ICDD 01-71-1490, Table 1) it can be seen that the positions of all measured reflections for (1) are in excellent, and the intensities in reasonable good agreement with chalconatronite, see also the experimental chalconatronite entry ICDD 22-1458 (Guinier camera, Table 1, right column). The agreement can be visualized by simulating a diffractogram from the structure [11] with a peak half width of $0.3^{\circ} / 2 \Theta$ (typical for measurements in the 1970's) and superimposing ICDD 28-1048 (grey bars, Fig. 1). There can be no doubt that Sengupta and Nandi also synthesized chalconatronite and not the basic sodium copper carbonate (1). The identity of the diffractograms has not been noticed as the important characteristic peaks at higher $d$-values were missing (because not measured) and the chalconatronite card 22-1458 of 1969 (with d > $1.8 \AA$ only) is of low quality (in modern standards) with intensities only estimated visually from a film.
Table 1 Comparison of XRPD data of (1) (ICDD 28-1048, middle) with chalconatronite: data calculated from the crystal structure ([14], left) and ICDD 22-1458 (right). Grey shaded fields: no measurement in that range

\begin{tabular}{|c|c|c|c|c|c|}
\hline \multicolumn{2}{|c|}{$\begin{array}{l}\text { Chalconatronite } \\
\text { ICDD 01-71- } \\
1490 \text {, calc. from } \\
{[14]}\end{array}$} & \multicolumn{2}{|c|}{$\begin{array}{l}\text { Bas. Na-Cu-carb. } \\
\text { ICDD } 28-1048 \\
\text { (1) }[6]\end{array}$} & \multicolumn{2}{|c|}{$\begin{array}{r}\text { Chalconatron. } \\
\text { ICDD 22-1458, } \\
\text { see also [13] }\end{array}$} \\
\hline$d$ & $\begin{array}{l}\text { Rel. } \\
\text { I [\%] }\end{array}$ & $d$ & $\begin{array}{l}\text { Rel. } \\
\text { I* [\%] }\end{array}$ & $d$ & $\begin{array}{l}\text { Rel. } \\
\text { I [\%] }\end{array}$ \\
\hline 8.0472 & 2.1 & & & 8.06 & 30 \\
\hline 7.8257 & 15.2 & & & 7.82 & 50 \\
\hline 6.9020 & 99.9 & & & 6.90 & 100 \\
\hline 5.5795 & 4.3 & & & 5.59 & 40 \\
\hline 5.1632 & 41.0 & & & 5.18 & 70 \\
\hline 4.8479 & 1.9 & & & 4.85 & 30 \\
\hline 4.8111 & 2.2 & & & 4.81 & 30 \\
\hline 4.5707 & 7.9 & & & 4.57 & 40 \\
\hline 4.2056 & 9.5 & & & 4.21 & 40 \\
\hline 4.1660 & 55.2 & 4.187 & $55.2 *$ & 4.18 & 80 \\
\hline 4.1100 & 19.1 & 4.101 & 17 & 4.10 & 50 \\
\hline 4.0236 & 1.4 & & & 4.05 & 20 \\
\hline 3.9129 & 2.9 & & & 3.91 & 30 \\
\hline 3.7953 & 2.3 & & & 3.80 & 30 \\
\hline 3.6734 & 37.4 & 3.678 & 39 & 3.68 & 90 \\
\hline 3.6380 & 6.2 & & & 3.63 & 40 \\
\hline 3.4510 & 10.7 & 3.453 & 33 & 3.45 & 40 \\
\hline 3.4085 & 3.3 & & & 3.41 & 30 \\
\hline 3.3588 & 6.3 & 3.361 & 5.5 & 3.37 & 40 \\
\hline 3.2935 & 0.7 & & & 3.29 & 10 \\
\hline 3.1677 & 0.6 & & & 3.17 & 20 \\
\hline 3.1263 & 4.7 & 3.123 & 7.2 & 3.12 & 40 \\
\hline 3.0500 & 0.4 & & & 3.04 & 10 \\
\hline 3.0036 & 13.5 & 3.002 & 17 & 3.00 & 50 \\
\hline 2.9782 & 2.8 & & & 2.98 & 40 \\
\hline 2.9618 & 0.4 & & & & \\
\hline 2.9094 & 7.0 & & & 2.91 & 50 \\
\hline 2.8903 & 14.9 & 2.891 & 19 & 2.89 & 60 \\
\hline \multirow[t]{2}{*}{2.8520} & \multirow[t]{2}{*}{24.3} & \multirow[t]{2}{*}{2.849} & \multirow[t]{2}{*}{19} & 2.852 & 70 \\
\hline & & & & 2.847 & 50 \\
\hline 2.7822 & 2.8 & & & 2.78 & 30 \\
\hline \multirow[b]{2}{*}{2.6762} & \multirow[b]{2}{*}{7.2} & \multirow[b]{2}{*}{2.676} & \multirow[b]{2}{*}{19} & 2.690 & 30 \\
\hline & & & & 2.673 & 50 \\
\hline 2.6637 & 1.8 & & & & \\
\hline
\end{tabular}


Table 1 continued

\begin{tabular}{|c|c|c|c|c|c|}
\hline 2.6347 & 1.9 & & & 2.63 & 20 \\
\hline 2.6148 & 7.5 & 2.608 & 8.3 & 2.612 & 40 \\
\hline 2.6086 & 6.9 & & & 2.605 & 40 \\
\hline 2.5833 & 1.4 & & & 2.59 & 20 \\
\hline 2.5422 & 1.0 & & & & \\
\hline 2.5304 & 8.8 & & & 2.53 & 60 \\
\hline 2.5152 & 9.6 & 2.515 & 11 & 2.51 & 60 \\
\hline 2.4690 & 0.5 & & & & \\
\hline 2.4555 & 5.0 & \multirow[t]{2}{*}{2.456} & \multirow[t]{2}{*}{5.5} & 2.46 & 40 \\
\hline 2.4493 & 2.5 & & & 2.45 & 20 \\
\hline 2.4306 & 14.5 & 2.428 & 11 & 2.43 & 60 \\
\hline 2.4239 & 8.9 & & & 2.425 & 40 \\
\hline 2.4055 & 2.9 & & & 2.405 & 30 \\
\hline 2.3985 & 3.8 & 2.396 & 2.8 & 2.395 & 40 \\
\hline 2.3085 & 0.2 & & & 2.31 & 20 \\
\hline 2.3007 & 0.2 & & & & \\
\hline 2.2854 & 0.9 & & & 2.28 & 30 \\
\hline 2.2661 & 7.3 & \multirow[t]{2}{*}{2.260} & \multirow[t]{2}{*}{14} & \multirow[t]{2}{*}{2.26} & \multirow[t]{2}{*}{60} \\
\hline 2.2577 & 5.7 & & & & \\
\hline 2.2330 & 1.9 & & & 2.238 & 30 \\
\hline 2.2291 & 1.8 & & & & \\
\hline 2.2147 & 3.6 & & & 2.21 & 40 \\
\hline 2.1971 & 1.6 & & & 2.20 & 30 \\
\hline 2.1832 & 0.2 & & & & \\
\hline 2.1724 & 1.3 & & & 2.17 & 30 \\
\hline 2.1591 & 0.6 & & & 2.16 & 20 \\
\hline 2.1526 & 1.0 & & & 2.15 & 20 \\
\hline 2.1306 & 4.4 & 2.132 & 9.9 & 2.135 & 40 \\
\hline 2.1139 & 0.1 & & & & \\
\hline 2.0994 & 0.6 & & & & \\
\hline 2.0830 & 20.2 & 2.082 & 14 & 2.082 & 60 \\
\hline 2.0691 & 11.0 & 2.063 & 7.7 & 2.061 & 60 \\
\hline 2.0517 & 2.6 & & & 2.050 & 40 \\
\hline \multirow[t]{2}{*}{2.0456} & 2.3 & & & & \\
\hline & & & & 2.015 & 30 \\
\hline 2.0116 & 14.2 & 2.012 & 11 & 2.010 & 60 \\
\hline 2.0015 & 3.5 & & & 1.999 & 30 \\
\hline 1.9900 & 7.1 & & & 1.991 & 60 \\
\hline 1.9824 & 1.0 & & & 1.982 & 20 \\
\hline 1.9680 & 1.1 & & & 1.969 & 30 \\
\hline
\end{tabular}

Table 1 continued

\begin{tabular}{|l|l|l|l|l|l|}
\hline 1.9564 & 0.2 & & & & \\
\cline { 1 - 2 } 1.9505 & 0.8 & & & 1.953 & 20 \\
\hline 1.9437 & 0.4 & & & & \\
\hline 1.9282 & 0.5 & & & 1.928 & 20 \\
\hline 1.9153 & 5.8 & 1.915 & 2.8 & 1.917 & 50 \\
\hline & & & & 1.910 & 30 \\
\hline 1.8976 & 5.8 & & & 1.898 & 50 \\
\hline 1.8835 & 0.1 & 1.883 & 3.3 & & \\
\hline 1.8709 & 0.6 & & & & \\
\hline 1.8598 & 2.9 & & & 1.860 & 40 \\
\hline 1.8480 & 8.3 & 1.847 & 5.5 & 1.848 & 60 \\
\hline 1.8385 & 1.4 & & & 1.839 & 30 \\
\hline 1.8326 & 0.4 & & & & \\
\hline 1.8306 & 0.4 & & & & \\
\hline 1.8225 & 0.9 & & & 1.821 & 30 \\
\hline 1.8150 & 0.9 & & & 1.818 & 30 \\
\hline 1.8043 & 0.8 & & & & \\
\hline 1.7979 & 2.5 & & & 1.800 & 40 \\
\hline 1.7667 & 6.0 & 1.765 & 8.3 & & \\
\hline 1.7519 & 1.0 & & & & \\
\hline 1.7434 & 3.0 & & & & \\
\hline 1.7335 & 5.6 & & & & \\
\hline 1.7255 & 2.4 & 1.725 & $8.3 b$ & & \\
\hline 1.7222 & 5.5 & & & & \\
\hline 1.7112 & 2.2 & & & & \\
\hline 1.7060 & 2.8 & 1.707 & 2.8 & & \\
\hline
\end{tabular}

$\mathrm{b}=$ broad

* I normalized to highest peak set to $55.2 \%$ for better comparison

It is no wonder then that in mixtures were chalconatronite is present also the basic sodium copper carbonate, ICDD 28-1048, can be proposed by peak matching software (as happened for the burial plate samples), and in that way enters analytical reports.

\section{IR-spectroscopy}

The authors measured IR-spectra for (1) $[5,6]$ and chalconatronite [5], but only published peak lists, which look 


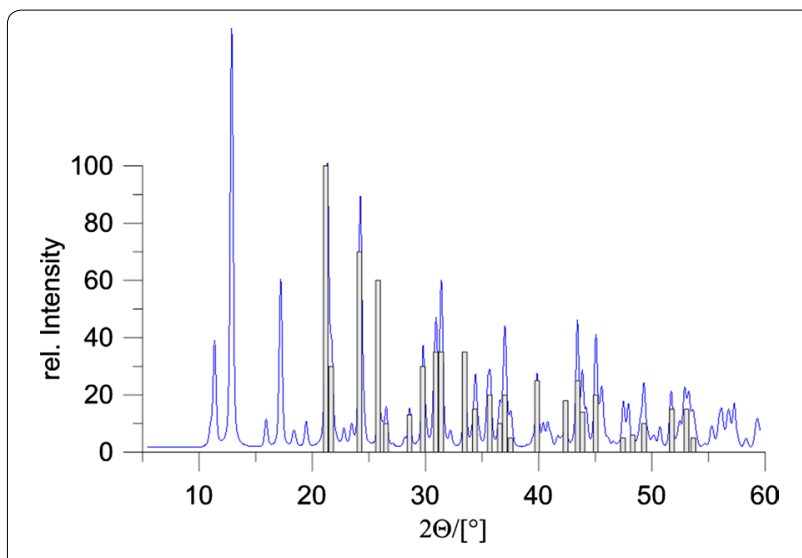

Fig. 1 Diffractogram simulated from structure [11] in comparison to ICDD 28-1084 (grey bars)

Table 2 Peaks in IR-spectra of (1) (left $[5,6])$ compared to chalconatronite [5] and [15]

\begin{tabular}{|c|c|c|}
\hline Compound (1) $[5,6]$ & Chalconatronite [5] & Chalconatronite [15] \\
\hline \multicolumn{3}{|l|}{$488-494(b, m)[6]$} \\
\hline $490(\mathrm{~m})[5]$ & $490(\mathrm{~m})$ & $500(m)$ \\
\hline \multicolumn{3}{|l|}{$457-566(b, m)[6]$} \\
\hline \multirow[t]{2}{*}{$562(\mathrm{~m})[5]$} & $562(\mathrm{~m})$ & $570(\mathrm{~m})$ \\
\hline & $630(w)$ & $645(f)$ \\
\hline $680(s)$ & $695(\mathrm{~m})$ & $700(\mathrm{~m})$ \\
\hline $748(s)$ & $750(s)$ & $750(F)$ \\
\hline $848(s)$ & $848(s)$ & $855(F)$ \\
\hline $1047(s)$ & $1047(s)$ & $1055(\mathrm{~m})$ \\
\hline \multicolumn{3}{|l|}{$1063(s)[6]$} \\
\hline $1063(\mathrm{~m})[5]$ & $1063(\mathrm{~m})$ & $1070(\mathrm{~m})$ \\
\hline $1325(\mathrm{~s})$ & $1320(s)$ & $1330(\mathrm{tF})$ \\
\hline $1350(d, s)$ & 1350 (d) & 1355 (tF) \\
\hline $1380(d, s)$ & 1380 (d) & $1385(\mathrm{tF})$ \\
\hline $1530(\mathrm{~s})$ & $1525(\mathrm{~s})$ & $1525(\mathrm{tF})$ \\
\hline $1600(s)[6]$ & $1600(s)$ & $1605(F)$ \\
\hline $1625(\mathrm{~m})[5]$ & $1625(\mathrm{~m})$ & \\
\hline $1640(w)$ & $1645(w)$ & \\
\hline \multicolumn{3}{|l|}{$1670(s)[6]$} \\
\hline $1670(\mathrm{~m})[5]$ & $1670(\mathrm{~m})$ & $1675(\mathrm{~m})$ \\
\hline \multirow[t]{2}{*}{$2125-2250(b, w)$} & $2310(w)$ & \\
\hline & $2900(w)$ & \\
\hline $3200(s)$ & $3200(s)$ & $3220(F)$ \\
\hline \multicolumn{3}{|l|}{ 3340-3400 (b, sh) [6] } \\
\hline \multicolumn{3}{|l|}{3375 (sh) [5] } \\
\hline $3430(s)$ & $3425(s)$ & $3450(F)$ \\
\hline \multicolumn{3}{|l|}{$3500(s)[6]$} \\
\hline $3550(\mathrm{~s})[5]$ & $3550(\mathrm{~s})$ & $3570(F)$ \\
\hline 3630 (sh) & & \\
\hline
\end{tabular}

$s$ strong, $m$ medium, $b$ broad, sh shoulder, $w$ weak, $d$ doublet

Right column: Abbreviations not explained: $t F$ très fort $(\approx \mathrm{vs})$ ?; $F$ fort $(\approx s)$ ?; $f=$ faible $(\approx w) ?$ very similar for both compounds (Note that lists for (1) vary slightly in the earlier conference contribution [5] and the journal article [6], Table 2). For many peaks, the chalconatronite spectrum [5] is even more similar to (1) than to a contemporary spectrum for chalconatronite [15] from another group (Table 2, right column). Therefore, there is no IR-spectroscopic proof that anything else than chalconatronite was measured and that (1) exists at all.

\section{Other physicochemical data reported by Sengupta and Nandi [6]}

- The authors found the same effective magnetic moments for (1) and for chalconatronite.

- The thermogravimetric curves for (1) and for chalconatronite differed somewhat, but one cannot assess from the publication if this difference is really beyond normal experimental error or could be caused by the presence of some amorphous material.

- Quantitative analytical data for $\mathrm{Na}^{+}, \mathrm{Cu}^{2+}$, and $\mathrm{CO}_{2}$ for their precipitate (1) led to the supposed formula, they do not fit the stoichiometry of chalconatronite. But we were unable to get a phase pure crystalline compound by their synthesis for (1), 10-14 \% amorphous material was present as well. From such a mixture, no meaningful stoichiometric formula can be derived by quantitative analysis of the mixture.

- The same holds true for the isothermal weight loss measured for (1) and chalconatronite (at slightly different temperatures $\left(150{ }^{\circ} \mathrm{C} / 160{ }^{\circ} \mathrm{C}\right)$.

\section{Conclusion}

Our synthetic replication experiments and a closer look at the diffraction data and the IR spectra show that Sengupta and Nandi $[5,6]$ have synthesized chalconatronite and not the basic sodium copper carbonate (1) they postulated. There is no experimental proof of any kind that the latter compound exists at all, neither as lab chemical, nor as corrosion product on heritage objects. Consequently, ICDD 28-1048 should be deleted.

The chalconatronite reference set ICDD 22-1458 of 1969 is still often used in metal heritage corrosion studies (e.g., [16-18]) for identification. To analyse complex mixtures, it should better be replaced by data derived from the crystal structure (e.g., ICDD 01-71-1490 or [19]) with quantitative values for intensities.

Authors' contributions

AF performed the synthesis experiments and characterized the precipitates with $\mu$-Raman spectroscopy. RD interpreted the XRD measurements and developed Fig. 1. GE had the idea for this study during a literature survey of rare corrosion products, developed Tables 1 and 2, and wrote the first draft of this communication. All authors read and approved the final manuscript. 


\section{Author details}

1 State Academy of Art and Design, Objects' Conservation, Am Weissenhof 1, 70191 Stuttgart, Germany. ${ }^{2}$ Scientific Service Group Diffraction, MaxPlanck-Institute for Solid Sate Research, Heisenbergstraße 1, 70569 Stuttgart, Germany.

\section{Acknowledgements}

We are grateful for the support of this study: C. Stefani performed the XRD measurements. A. Wollmann synthesized a chalconatronite reference sample. P. Bellendorf made copies of his diffractograms available to us. The Glass-Metal Corrosion Research is currently funded by the German Federal Environmental Foundation (DBU, Az. 33255/01).

\section{Competing interests}

The authors declare that they have no competing interests.

Received: 16 May 2016 Accepted: 10 June 2016

Published online: 25 July 2016

\section{References}

1. Sage M. Observations sur la Mine rouge de Cuivre. Observations sur la Physique, sur l'Histoire Naturelle et sur les Arts. 1779;14:155-57.

2. Euler $\mathrm{H}$, Barbier B, Kirfel A, Haseloff S, Eggert G. Crystal structure of trihydroxydicopper formate, $\mathrm{Cu}_{2}(\mathrm{OH})_{3}(\mathrm{HCOO})$. Z Kristallogr NCS. 2009;224:609-10

3. Eggert $\mathrm{G}$, Haseloff $\mathrm{S}$, Euler $\mathrm{H}$, Barbier B. When glass and metal corrode together, III: The Formation of Dicoppertrihydroxyformate. J Bridgland editor. ICOM-CC 16th Triennial Conference Lisbon, 19-23 Sept 2011. Lisbon: Critério-Produção. 2011. p. 9.

4. Dinnebier RE, Runčevski T, Fischer A, Eggert G. Solid-state structure of a degradation product frequently observed on historic metal objects. Inorg Chem. 2015;54:2638-42.

5. Nandi AK, Sengupta AK. Carbonato Complexes of Copper(II). Proc Chem Symp 1972 Aligarh Muslim University. New Delhi: Dept of Atomic Energy, Gov of India. 1973; Vol. 2:115-120.

6. Sengupta AK, Nandi AK. Complex carbonates of copper (II). J Inorg Nucl Chem. 1974;36:2479-84
7. Eggert G. Corroding glass, corroding metals: survey of joint glass/ metal corrosion products on historic objects. Corr Eng Sci Technol. 2010:45:414-9.

8. Barger MS, White WB. The Daguerreotype. Washington (DC): Smithsonian Institution Press; 1991. p. 167

9. Barger MS, Smith DK, White WB. Characterization of corrosion products on old protective glass, especially daquerreotype cover glasses. J Mat Sci. 1989;24:1343-56.

10. Bellendorf P. Metallene Grabplatten aus Franken und Thüringen aus dem 15. bis 18. Jahrhundert-eine interdisziplinäre Studie zum Denkmalbestand und seiner Gefährdung durch Umwelteinflüsse. Ph.D. Dissertation. Bamberg: Otto-Friedrich Universität; 2007. urn:nbn:de:bvb:473-opus-1368.

11. Mukhopadyhay $U$, Bernal I. A totally unexpected synthesis of single crystals of the mineral chalconatronite, $\mathrm{Na}_{2}\left(\mathrm{Cu}\left(\mathrm{CO}_{3}\right)_{2}\right) \cdot 3\left(\mathrm{H}_{2} \mathrm{O}\right)$, from a solution of a copper coordination compound and atmospheric $\mathrm{CO}_{2}$ at room temperature. J Coord Chem. 2004;57:353-60.

12. Gettens RJ, Frondel C. Chalconatronite: an alteration product on some ancient Egyptian bronzes. Stud Cons. 1955;2:64-75.

13. Erdös E. Natriumcarbonatocuprat(II) — trihydrat als Korrosionsprodukt von Kupfer. Corr Sci. 1969;9:435-7.

14. Brotherton D, White AH. Crystal Structures of copper(II) sodium carbonate trihydrate (chalconatronite). J Chem Soc Dalton Trans. 1973;21:2338-40.

15. Taravel B, Berjot M, Fromage F. Étude structurale par spectrométrie infrarouge et Raman du dicarbonatocuprate (II) de sodium. CR Acad Soc Paris Série B. 1974;279:159-61.

16. Scott DA. Copper and bronze in art-corrosion, colorants, conservation. Los Angeles: GCl. 2002:424,446.

17. Scott DA, Dodd L. Examination, conservation and analysis of a gilded Egyptian bronze osiris. J Cult Her. 2009;3:342

18. Wang $\mathrm{Q}$ Huang $H$, Shearman $F$. Bronzes from the sacred animal necropolis at Saqqara, Egypt: a study of the metals and corrosion. Brit Mus Techn Bull. 2009;3:77.

19. WWW-MINCRYST (2016). Crystallographic and crystallochemical database for minerals and their structural analogues. http://database. iem.ac.ru/mincryst, accessed 07 Mar 2016. Full Information Card Chalconatronite-835.

\section{Submit your manuscript to a SpringerOpen ${ }^{\odot}$ journal and benefit from:}

- Convenient online submission

- Rigorous peer review

- Immediate publication on acceptance

- Open access: articles freely available online

- High visibility within the field

- Retaining the copyright to your article 